\title{
William Butcher, Jules Verne inédit, les manuscrits déchiffrés
}

\section{Ida Merello}

\section{(2) OpenEdition}

1 Journals

\section{Edizione digitale}

URL: http://journals.openedition.org/studifrancesi/1430

DOI: 10.4000/studifrancesi. 1430

ISSN: 2421-5856

\section{Editore}

Rosenberg \& Sellier

\section{Edizione cartacea}

Data di pubblicazione: 1 décembre 2015

Paginazione: 623

ISSN: 0039-2944

\section{Notizia bibliografica digitale}

Ida Merello, «William Butcher, Jules Verne inédit, les manuscrits déchiffrés», Studi Francesi [Online], 177 (LIX | III) | 2015, online dal 01 décembre 2015, consultato il 11 janvier 2021. URL: http:// journals.openedition.org/studifrancesi/1430 ; DOI: https://doi.org/10.4000/studifrancesi.1430

Questo documento è stato generato automaticamente il 11 janvier 2021.

\section{(c) (i) $\odot$}

Studi Francesi è distribuita con Licenza Creative Commons Attribuzione - Non commerciale - Non opere derivate 4.0 Internazionale. 


\title{
William Butcher, Jules Verne inédit, les manuscrits déchiffrés
}

\author{
Ida Merello
}

\section{NOTIZIA}

WILLIAM BUTCHER, Jules Verne inédit, les manuscrits déchiffrés, Lyon, Ens éditions 2015, pp. 490.

1 Testo fondamentale per seguire l'evoluzione della scrittura di Jules Verne, ma anche per definire i rapporti con l'editore Hetzel padre, propone un'amplissima raccolta di citazioni tratte dai brouillons scritti da Verne tra il 1859 e il 1879. L'A. dichiara la sua distanza da tutte le metodologie, ma il controllo costante della biografia, attraverso la corrispondenza, per poter organizzare i materiali e comprendere le ragioni che hanno portato alle modifiche. Il corpus è infatti molto vario, di difficile datazione, e di circa un milione e mezzo di parole. W. Butcher ha deciso di decifrare sistematicamente solo gli inizi, i finali e i passaggi sconosciuti, inventando un sistema tipografico che permette di visualizzare molto bene i vari stati del testo. Particolarmente interessanti i rapporti che emergono tra Verne e Hetzel padre, preoccupato di censurare qualsiasi contenuto che possa turbare le giovani menti dei rampolli borghesi, e di cambiare i titoli, cercando alternative efficaci a quelli proposti dallo scrittore. 